\title{
Validity and Reliability of Talent Identification Instrument in Archery
}

\author{
Wisnu Nugroho ${ }^{1, *}$ Endang Rini Sukamti ${ }^{1,}$ Ratna Budiarti ${ }^{1,}$ Sb. Pranatahadi ${ }^{1}$ \\ ${ }^{I}$ Faculty of Sport Science, Yogyakarta State University, Yogyakarta, Indonesia \\ *Corresponding author. Email: wisnunugroho.2020@student.uny.ac.id
}

\begin{abstract}
Archery is a sport which promotes Indonesia internationally. Talent identification is needed for the regeneration of archery athletes in order to reach the peak of achievement. The aim of this study is to develop an effective and efficient talent identification instrument in archery. This study uses a mix of qualitative and quantitative methods. The participants are 7 experts ( 4 archery coaches, 3 archery lecturers) and 61 archery athletes. There are four steps of research procedures in this study. In the first step, documents in the form of international journals are analyzed to develop a talent identification instrument in archery. The second step involves a process of expert validation by using Delphi technique. In the third step, the process is continued by doing qualitative analysis on the input from expert judgment. Then, the results are analyzed and revised until it is accepted by the experts without any further revision. The research instrument of this study is a questionnaire with a scoring scale of 1 to 4 , namely very relevant, relevant, less relevant, and irrelevant. Data analysis uses the Aiken formula. In the last step, it includes the process of conducting tests to determine the reliability of the talent identification instrument in archery. The data are analyzed using SPSS. The results of this study show the system of the talent identification instrument in which: (1) the suitability of the instrument material has the V's coefficient value of 0,857 ; (2) the relevant instrument construction of each element in the archery talent identification has the V's coefficient value of 0,952 ; (3) the implementation procedures have V's coefficient value of 0,809 ; (4) the safety of the instrument has the V's coefficient value of 0,857 ; (5) the ease of conducting the archery talent identification test has the V's coefficient value of 0,857 . The value of the instrument reliability test is 0,635 . Hence, the talent identification instrument in archery is valid and reliable.
\end{abstract}

Keywords: Instrument, Archery, Talent, Identification

\section{INTRODUCTION}

Archery grows more broadly in Indonesia. It is a sport where the goal is to shoot arrows precisely at the target. Internationally, archery is divided into two divisions which are recurve and compound. However, in Indonesia, it is divided into three divisions which are recurve, compound, and standard bow [1].

This sport is one of the sports which raises Yogyakarta in the world of sports. Archery has been a regular feature in the Olympics and there have been archery athletes from Yogyakarta who compete internationally for Indonesia. Achievement in archery in Yogyakarta must be maintained and regenerated in order to scout new talented athletes, hence the archery achievement in Yogyakarta remains well. One of the attempts to scout talented archery athletes is by doing talent identification from an early age. The cause of why Indonesia left behind in terms of sports achievement is due to lack of attention to search for talented athletes as an effort to regenerate athletes in the future [2].

Through field observations, talent identification instrument in archery currently relies on the observation approach and experience of the coaches. It happens because there is a lack of a standard pattern of talent identification done in this sport. Archery coaches especially in Yogyakarta tend to train athletes without considering whether the athletes are talented or potential to be improved to achieve achievements in archery. Therefore, a talent identification system is needed and must be done evenly to attract potential athletes.

The talent identification system is not something which stands alone, but it is a combination of various work aspects. Because of that, it is necessary to have a study on how to develop and create an effective implementation system of talent identification by optimizing the existing potential. There are many ways of finding potential athletes who can be trained 
for achievement based training. According to [3], in a process of training, talent identification is an early stage that must be done in the early age (grass root). Early talent identification is expected to be the first step in the training process to gain achievements [4]. That process needs to be done. In order to achieve that, there are things that must be considered, thus every stage in the training process goes well and correctly.

Talent needs to be recognized from an early age in a way that it can be properly trained to develop quality athletes [5]. Identifying talented individuals especially in sports and directing them to their relevant sports are important for their success in sports [6]. Talent identification is a process of selecting prospective athletes which includes a process of measuring various internal qualities of athletes such as physical quality, anthropometry, motor quality, and psychological quality [7].

In addition to basic technical skills, good biomotor abilities are needed for athletes to reach their highest of achievements. Data on physical condition in the forms of athletes' biomotor components is necessary to arrange training periodization. Information about the conditions or the physical abilities of athletes becomes urgently needed during training or developing overall athletes' physical conditions. Athletes' physical conditions are important in sports, because athletes must have excellent physical conditions to win [8]. Physical conditions are the fundamental foundation that must pay attention to among other aspects to obtain a perfect training quality in achieving a maximum performance during competitions. It contains basic biomotor components which consist of strength, endurance, flexibility, and speed [9].

There has not been a guide or instrument in developing a talent identification system especially in archery. Based on the background stated, this study aims to develop a talent identification instrument in archery. With the data on biomotor components of prospective athletes as a whole combined with various talent item tests in archery, it can create an effective and efficient talent identification model in archery.

\section{MethodS}

This study uses mix methods. It combines two approaches which are qualitative and quantitative to gather complete and valid data. The participants of this study were documents, 7 experts, and 61 archery athletes. The experts had qualifications as 4 archery coaches and 3 archery lecturers. There were four stages done in this study.

In the first step, a qualitative approach was done with literature review methods with the type of narrative review [10]. Articles, journals, and text books related to the talent identification instruments existing were used to develop and construct a conceptual and operational definition of the talent identification instrument.

In the second step, content validity tests by using Delphi technique were done $[11,12,13]$. In this technique, every expert did not meet during the assessment of the instrument. In the third step, it is continued with a qualitative analysis of the expert judgment. The results were analyzed and revised until the experts accepted it without any further revision [14] and gave scores to the construction of the talent identification instrument in archery. The research instrument of this study is in the form of a questionnaire with a scoring scale of 1 to 4, namely very relevant, relevant, less relevant, and irrelevant. The formula of data analysis used was the Aiken's V [15] presented as follows:

$\mathrm{V}=\left(\sum(\right.$ ri-lo $\left.)\right) /[\mathrm{n}(\mathrm{c}-1)]$

$\mathrm{V}=$ index of rater agreement regarding the validity of items

$\mathrm{r}=$ the score given by a rater

lo $=$ the lowest validity score ( 1 out of a scale of 1-4)

$\mathrm{c}=$ the highest validity score ( 4 out of a scale of $1-4$ )

$\mathrm{n}=$ the number of raters who assess

In the last step, content validity tests were performed to determine the reliability of the talent identification instrument. The test subjects were 28 athletes from Selabora FIK UNY, 26 athletes from Blangkon Archery, and 7 athletes from Bamboe Roentjing Arc. The data analysis technique in order to estimate the reliability of the instrument used an internal consistency estimation technique with the Cronbach-alpha formula done in SPSS IBM 20. If the Cronbach-alpha value is 0,60 and is below 1 , then the instrument has high correlation or reliability. However, if the Cronbach-alpha value is under 0,50 , it has low correlation and is not reliable [16]. It is in line with [17], that the reliability coefficient of 0,5 can be used for research purposes.

\section{RESULTS}

The results of document analysis present the definition of talent identification in archery. Talent identification in archery is one of the ways to identify and select prospective athletes who have high potential and abilities in archery. The results of the development are in the form of a test of a talent identification instrument in archery which is qualifying and practical. Moreover, the talent identification instrument in archery can be seen in Table 1 . 
Table 1. The Table of the Talent Identification Instrument in Archery.

\begin{tabular}{|c|l|}
\hline No. & \multicolumn{1}{|c|}{ Test Items } \\
\hline 1. & Height/Weight/Arm Span \\
\hline 2. & Kinesthetic Perception Test \\
\hline 3. & Sit and Reach \\
\hline 4. & Standing Balance \\
\hline 5. & Wallseat \\
\hline 6. & Side Learning Rest \\
\hline 7. & Hand Dynamo Meter \\
\hline 8. & VO2Max (MFT) \\
\hline 9. & Skill Test \\
\hline
\end{tabular}

\subsection{The Results of Content Validity Tests}

Table 2. The results of content validity tests of Aiken's

\begin{tabular}{|c|c|c|c|c|c|c|c|c|c|c|}
\hline \multirow[b]{2}{*}{ Rater } & \multicolumn{2}{|c|}{ Aspect 1} & \multicolumn{2}{|c|}{ Aspect 2} & \multicolumn{2}{|c|}{ Aspect 3} & \multicolumn{2}{|c|}{ Aspect 4} & \multicolumn{2}{|c|}{ Aspect 5} \\
\hline & $\begin{array}{c}\begin{array}{c}\text { Sco } \\
\text { re }\end{array} \\
\end{array}$ & S & $\begin{array}{c}\text { Sco } \\
\text { re }\end{array}$ & S & $\begin{array}{c}\text { Sco } \\
\text { re }\end{array}$ & S & $\begin{array}{c}\text { Sco } \\
\text { re }\end{array}$ & S & \begin{tabular}{c|} 
Sco \\
re
\end{tabular} & S \\
\hline 1 & 4 & 3 & 4 & 3 & 4 & 3 & 4 & 3 & 4 & 3 \\
\hline 2 & 4 & 3 & 4 & 3 & 4 & 3 & 4 & 3 & 3 & 2 \\
\hline 3 & 3 & 2 & 4 & 3 & 3 & 2 & 4 & 3 & 3 & 2 \\
\hline 4 & 3 & 2 & 3 & 2 & 3 & 2 & 3 & 2 & 4 & 3 \\
\hline 5 & 3 & 2 & 3 & 3 & 3 & 2 & 3 & 2 & 4 & 3 \\
\hline 6 & 4 & 3 & 4 & 3 & 3 & 2 & 3 & 2 & 4 & 3 \\
\hline 7 & 4 & 3 & 4 & 3 & 4 & 3 & 4 & 3 & 3 & 2 \\
\hline$\sum S$ & & 18 & & 20 & & 17 & & 18 & & 18 \\
\hline $\mathbf{V}$ & & $\begin{array}{r}0,85714 \\
3 \\
\end{array}$ & & $\begin{array}{r}0,95238 \\
1\end{array}$ & & $\begin{array}{r}0,80952 \\
4\end{array}$ & & $\begin{array}{r}0,85714 \\
3\end{array}$ & & $\begin{array}{r}0,85714 \\
3 \\
\end{array}$ \\
\hline
\end{tabular}

Based on Table 2, aspect 1 to 5 has coefficient value as follows: (1) the suitability of the instrument material has the V's coefficient value of 0,857 ; (2) the relevant instrument construction of each element in the archery talent identification has the V's coefficient value of 0,952 ; (3) the implementation procedures have V's coefficient value of 0,809 ; (4) the safety of the instrument has the V's coefficient value of 0,857 ; (5) the ease of conducting the archery talent identification test has the V's coefficient value of 0,857. In the Aiken $\mathrm{V}$ table (Aiken, 1985) with raters of 7 and a scale of 4 , it resulted in the minimum criterion value of Aiken with a minimum range of $\mathrm{V}$ values of $0,76-0,86$. It implies that the raters strongly agree with their own opinion. Based on the explanation, it means that the instrument has high validity. In other words, all raters have high agreement.

\subsection{The Results of the Reliability Tests}

According to the test results of the instrument on 61 archery athletes, the Cronbach's Alpha's reliability value is presented as follows:
Table 3. Reliability Statistics

\begin{tabular}{|c|c|}
\hline Cronbach's Alpha & N of Items \\
\hline, 635 & 11 \\
\hline
\end{tabular}

The reliability value of the Cronbach's Alpha is 0,635. It means that the talent identification instrument has good reliability. If the value of the Cronbach's Alpha is 0,60 or below 1 , it means that the instrument is reliable. On the other hand, if the value of Cronbach's Alpha is under 0,50, it means that the instrument is unreliable [16].

\section{DISCUSSION}

Talent identification is a way done systematically to identify someone who has potential in sports. Based on that limit, talent identification is a process of selecting prospective athletes that involves the process of measuring various internal qualities of athletes, such as anthropometric, physical, motor, and psychological quality using predetermined instruments. This process is often called as the selection stage conducted before a training process to ensure that children or prospective athletes involved really have high potencies in accordance with the needs and demands in archery, can be trained successfully and achieve their peak of performance [18]. In performance sports, the role of selection is to scout children who have outstanding skills and qualities or are the most gifted [19].

The process of talent identification in archery is an important component during the process of preparing athletes in the long term (10 years in the future). Archery talent identification is a screening process of children by using certain physical, physiological, and skill tests to identify their potencies in order to succeed in the chosen sport activity. The purpose of talent identification is to recognize and select children who have potential talent in sports to be trained into athletes who are capable and can achieve maximum results or achievement [20]. Hence, it is important to identify talented prospective athletes to be able to achieve maximum results.

This instrument developed is a valid and reliable instrument to measure the athletes' abilities to be more successful. Content validity is a test model which reflects the overall measured abilities [21], whereas reliability is the degree of consistency between two results of measurements on the same objects [22].

The results of the talent identification instrument in archery are as follows: (1) the suitability of the instrument material has the V's coefficient value of 0,857 ; (2) the relevant instrument construction of each element in the archery talent identification has the V's coefficient value of 0,952 ; (3) the implementation procedures have V's coefficient value of 0,809 ; (4) the safety of the instrument has the V's coefficient value 
of 0,857 ; (5) the ease of conducting the archery talent identification test has the V's coefficient value of 0,857 . In addition, the reliability of the instrument that has been tested on 61 archery athletes has a value of 0,635 .

Based on the explanation, the content validity of the instrument which has a coefficient value more than 0,76 is categorized as valid, and the reliability value is above 0,6 . It means that the instrument is reliable.

\section{CONCLUSIONS}

The talent identification instrument in archery has high validity and reliability value. With the development of the instrument, it can help coaches to identify their athletes and other researcher as a reference regarding talent identification instruments in archery.

\section{ACKNOWLEDGMENT}

The author would like to thank Yogyakarta State University, Selabora FIK UNY, Blangkon Archery, and Bamboe Roentjing Arc for helping and giving the opportunity to conduct and collect data, so that this article can be done completely. And hopefully, this article can be useful for coaches, other researchers, and readers.

\section{REFERENCES}

[1] Kadek Dian Vanagosi. 2015. Analisis Kinesiologi Teknik Cabang Olahraga Panahan. Jurnal Pendidikan Kesehatan Rekreasi Vol 1, 70 -75

[2] Kusnanik, M. W. (2014). Model pengukuran antrophometrik, fisiologis, dan biomotorik dalam mengidentifikasi bibit atlet berbakat cabang olahraga sepakbola. Proceeding hal (146-157). Fakultas Ilmu Keolahragaan Universitas Negeri Surabaya, Surabaya.

[3] Beswick, Bill. (2010). Focused for soccer (second edition). United States of America: Human Kinetics.

[4] Ade Evriansyah Lubis , Mawardinur , Ratna Dewi. 2020. Talent Scouting Atlet Sepak Bola Usia 10 Sampai 11 Tahun. Jurnal Pendidikan Jasmani. Vol. 1, (1), 29-32

[5] Pruna, R., \& Tribaldos, L. M. 2018. Player talent identification and development in foot ball. Apuntsn Medicina De L'eSport, 53 (198), 43-46.

[6] Kaynar, Ö. (2019). Investigation of Talent Selection Methods in Different Sports Branches. 6(12), 44-48. https://doi.org/10.11114/jets.v6i12a.3925

[7] Depdiknas. Kerangka Dasar Kurikulum 2004. Jakarta
[8] Mansur, L. K., Irianto, D. P., \& Mansur. (2018). Pengaruh latihan squat menggunakan free weigh dan gym machine terhadap kekuatan, power, dan hypertrophy otot. Jurnal Keolahragaan, 6, 152-3.

[9] Bompa T \& Carlo Buzzichelli. Periodization training for sports. (2019).United States: Human Kinetics.

[10] Rossella Ferrari. (2015). Writing narrative style literature reviews. Journal Medical Writing. Volume 24, Issue 4, 230-235

[11] Chia-Chien Hsu \& Brian A. Sandford. (2007). The Delphi Technique: Making Sense Of Consensus. Practical Assessment, Research \& Evaluation, Vol 12, Art 10, 1-5.

[12] Cox, G. R., Bailey, E., Jorm, A. F., Reavley, N. J., Templer, K., Parker, A., ... Robinson, J. (2016). Development of suicide postvention guidelines for secondary schools: a Delphi study. BMC Public Health, 16(1), 180. doi:10.1186/s12889-016-2822-6

[13] Green, R. A. (2014). The Delphi Technique in Educational Research. SAGE Journals 4(2), 417425. doi:10.1177/2158244014529773

[14] Fraenkel, Jack. R., and Norman E. Wallen. 2012. How to Design and Evaluate Research in Education 8th Edition. Boston: McGraw-Hill Higher Education

[15]Aiken, L R. (1985). Three coefficients for analyzing the reliability and validity of ratings. Educational and Psycological Measurement, 45(1), 131-141. doi:10.1177/0013164485451012.

[16]Basuki, I., \& Hariyanto. (2014). Asesemen pembelajaran. Bandung: PT. Remaja Rosdakarya.

[17] Surapranata, S. (2009). Analisis, validitas, reliabilitas, dan interpretasihasil tes implementasi kurikulum 2004. Bandung: PT. Remaja Rosdakarya.

[18]Cholik Mutohir, T. 2002. Gagasan-gagasan tentang Pendidikan Jasmani dan Olahraga. Unesa University Press:Surabaya.

[19] Olaru, Maria. (2009). "Selection in Artistics Gymnastics". Timisoara Physical Education and Rehabilitation Journal, Vol I. Timisoara: West University

[20] Siswantoyo. (2009). Pemanduan bakat olahraga. Fakultas Ilmu Keolahragaan. UNY.

[21] Azwar, S. (2011). Reliabilitas dan validitas. Yogyakarta: Pustaka Belajar.

[22] Mehrens, W.A. \& Lehmann, I.J. (1973). Measurement and evaluation in education and psychology. New York : Hold, Rinehart and Wiston,Inc. 